\title{
Eocene antiquity of the European nyctitheriid euarchontan mammal Darbonetus
}

\author{
Jerry J. Hooker \\ Acta Palaeontologica Polonica 63 (2), 2018: 235-239 doi:https://doi.org/10.4202/app.00457.2018
}

Until now Darbonetus was represented by only one valid species, the type species D. aubrelongensis from the early Oligocene of the Quercy region, France. A late appearance of this genus and of its closest relative Amphidozotherium have been thought to result from dispersal from outside western Europe, rather than a local ancestry earlier in the late Eocene. Here, a new species, Darbonetus sigei sp. nov., is described from the middle Priabonian site of La Débruge, France. Although clearly closely related to D. aubrelongensis, D. sigei shows less reduction of its $\mathrm{p} 2, \mathrm{p} 3$, and $\mathrm{m} 3$ than in the more derived type species. The early age of D. sigei suggests that its origins were within the still isolated central European island and that it is unnecessary to invoke dispersal from another continent.

Jerry J. Hooker [j.hooker@nhm.ac.uk], Department of Earth Sciences, Natural History Museum, Cromwell Road, London SW7 5BD, UK.

This is an open-access article distributed under the terms of the Creative Commons Attribution License (for details please see creativecommons.org), which permits unrestricted use, distribution, and reproduction in any medium, provided the original author and source are credited.

Fof Full text $(172.3 \mathrm{kB})$ 